\title{
No Love on the Dole: The Influence of the UK Means-tested Welfare System on Partnering and Family Structure
}

\author{
RITA GRIFFITHS \\ Institute for Policy Research, University of Bath, Claverton Down, Bath, Somerset BA2 7AY, \\ United Kingdom \\ email: r.l.griffiths@bath.ac.uk; rita@insiteresearch.co.uk
}

\begin{abstract}
Two-parent families with dependent children are known to be at lower risk of poverty and significantly less reliant on state financial help than lone-parent households. It might therefore be expected that the factors influencing partnership transitions among low-income women would represent a key area of policy interest. However, driven by concerns about weak work incentives, policy focus and research has to date concentrated on understanding lone parents' labour supply and encouraging the transition from benefits into employment. Surprisingly little is therefore known about demographic decision making among women reliant on UK means-tested welfare. As part of a wider qualitative study exploring family formation, partnership dissolution and repartnering decisions among low-income mothers, this paper examines whether and to what extent entitlement to welfare benefits or tax credits influenced the decision to live with or apart from a partner or child's father. The research found that the aspects of welfare that remove or reduce a mother's access to an independent income and require one partner in a couple to be financially dependent on the other had been strongly influential in partnering decisions and living arrangements. Policy implications are discussed.
\end{abstract}

\section{Introduction and policy context}

In the UK, there are more lone parents and fewer married-couple families with dependent children than ever before (ONS, 2015). Also rising is the proportion of unmarried women becoming lone mothers following the breakdown of a cohabiting union and through the birth of a child outside of a co-residential partnership (Kiernan, 2006). This increasing diversity in family form and structure is of interest and concern to social scientists, politicians and policy makers because child poverty, child outcomes and the extent of a family's reliance on state financial help are strongly associated with whether or not the mother is in a co-residential union (Bradshaw, 2011; Crawford et al., 2012). The factors influencing family formation, relationship stability and repartnering among mothers claiming benefits or tax credits might therefore be expected to represent 
key areas of policy interest and research. However, driven by concerns about weak work incentives and the belief that paid employment is the best route out of poverty, policy focus and research has, to date, concentrated on understanding lone parents' labour supply and encouraging the transition from benefits into employment.

During New Labour's period in office, normative assumptions about family structure mattered much less than did reducing the number of lone-parent families claiming out-of-work benefits (Barlow et al., 2002). The coming to power of the Coalition government in 2010 heralded a marked shift of approach and tone. 'Making work pay' remained the cornerstone of Universal Credit, the Conservative Party's flagship welfare reform policy, but a key emerging message was that poverty is less about income inequality and material deprivation and more about a poor family environment and inadequate parenting (Lister and Bennett, 2010). Social security cuts, a tougher regime of work conditionality and escalating benefit sanctions have further eroded the former policy focus on improving the incomes of the poorest households.

Rejecting 'the comfortable mantra that policy can or should be wholly morally neutral' (SJPG, 2006: 9), 'family breakdown' has increasingly been identified as a driver of children's reduced life chances. With the reintroduction of a marriage tax allowance in $2015^{1}$, couple relationships and family functioning have increasingly been positioned centre-stage as key elements of the Conservative government's strategy for improving child outcomes and reducing child poverty. Politicians and policy makers who lament the decline of the traditional two-parent family have called for changes in the tax and benefit system to promote marriage and abolish the 'couple penalty', so-called to describe financial differentials in welfare entitlement seen to favour lone parents to the detriment of twoparent families (The Centre for Social Justice, 2010). Some allege this differential incentivises lone motherhood, discourages marriage and encourages partnership dissolution, others that it fosters welfare dependency and benefit fraud among couples who, for reasons of monetary gain, may 'pretend to separate' or fail to disclose the presence of a co-resident partner (Chapman, 2011).

A favoured trope of the tabloids, the single mother incentivised to maximise her benefit entitlement by living apart or 'pretending to separate' from a partner is a powerful and persistent narrative. However, surprisingly little UK research has explored how low-income women actually make partnering decisions. The doctoral study from which this article draws contributes to filling this gap. Using face-to-face interviews with a diverse sample of 51 current and former lone mothers living in Merseyside, the research investigated whether, and to what extent, eligibility for or entitlement to benefits or tax credits may have influenced family formation, partnership dissolution or repartnering decisions in the period between 1997 and 2013. To help situate the research, interviews and focus groups were held with local family support, housing and welfare rights workers. 
Drawing on the research findings, this paper examines whether, and to what extent, entitlement to welfare benefits or tax credits influenced a mother's decision to live with or apart from a partner or child's father. It begins with a brief exploration of the association between family structure and welfare receipt in literature and research, goes on to describe the methodological and ethical approach adopted by the study, then presents empirical findings. Finally, the discussion considers the theoretical and policy implications.

\section{The influence of welfare systems on family structure}

In the 1990s, fuelled by the controversial work of US social commentator, Charles Murray (Murray, 1989), the question of whether the welfare system is undermining traditional family structures was vociferously debated by academics and social commentators (Robinson and Gregson, 1992; Macnicol, 1994). Welfare policies that allow a woman to support a child without a resident father were viewed by Murray and his exponents as displacing the married, twoparent family as an institution within which to raise and socialise children. Murray's inflammatory language and use of anecdotal evidence in the 'gross form of caricature' (Mann and Roseneil, 1994) was systematically discredited by academics at the time (Lister, 1996). Twenty five years on, amidst swingeing social security cuts and a hardening of public attitudes towards welfare recipients (Taylor-Gooby and Martin, 2008), fuelled by an increasingly hostile media, Murray's views are enjoying something of a renaissance (Prideaux, 2010). Through 'subsidising the choice to be a lone parent' (Morgan, 2008), in popular understanding, the perception that 'family breakdown' is the product of an over-generous welfare state that privileges lone parents has become increasingly mainstream amid waning public sympathy for 'welfare dependents' more generally (Kellner, 2012).

Despite being the perennial targets of welfare reform, relatively little is known in fact about how women who are reliant on UK state financial help make family formation, family dissolution and repartnering decisions; and across economic, sociology and social policy disciplines, the topic is under-theorised and under-researched. Pioneering sociological research into 'family practices' and 'Living Apart Together' (LAT) relationships have succeeded in challenging the norm of the white, heterosexual, married couple family (Roseneil, 2006; Morgan, 2011; Upton-Davis, 2012). However, studies of women who have made a conscious choice to have a child without a partner show them to be mostly welleducated and not in receipt of benefits (Klett-Davies, 2012). And while studies of poorly educated single women indicate that, for some, early motherhood can be transformative (Middleton, 2011), the idea that lone motherhood is pioneering and emancipating is not easily reconciled with its concentration among the poorest women in the poorest areas' (Webster, 1999: 8). Nor does the narrative 
of lone motherhood as 'a lifestyle choice' reflect the fact that, in the UK, the vast majority of women become lone mothers following the breakdown of a marital or cohabiting union (ONS, 2015).

Recent research has helped to dispel the more egregious cultural representations of benefit recipients as members of an underclass with welfare dependent cultures (Shildrick et al., 2012; Macdonald et al., 2014) but, compared with previous decades, the issue of whether and how the welfare system may affect family structure has received little scholarly attention. To date, most empirical research emanates from the US where the cultural context, socio-economic circumstances and institutional arrangements for the public assistance of poor families with children is substantively different to the UK (Edin and Kefalas, 2006; McLanahan, 2009; Blau and Van Der Klaauw, 2013). The few UK studies to have explored welfare effects on family structure are mostly econometric analyses of single policy interventions; these have, like US research, produced conflicting and inconclusive findings (Walker and Zhu, 2006; Brewer et al., 2012; Anderberg, 2008).

\section{The influence of gendered aspects of welfare}

The starting point for this research was to widen investigation of welfare influences beyond financial incentives to include consideration of the Living Together as a Married Couple (LTAMC) rule $^{2}$ and family-based system of means testing. Based on outdated notions of sole breadwinning, contested assumptions about income pooling and financial obligations in couples, and a definition of cohabitation as 'marriage-like', these aspects of UK social security have important gendered effects. Under these rules, married and cohabiting couples who share the same household have no individual right to claim means-tested benefits or tax credits; if eligible for help, they must claim jointly as a couple. Entitlement is assessed against their aggregated needs and income and only one person in the couple is entitled to claim; the other is treated as a dependent. Although either member of a couple can be the claimant, labour market inequalities and women's typically lower earning potential and generally greater caring responsibilities mean that, in opposite sex couple households with dependent children, it is rarely the woman who claims on behalf of the family (Bennett, 2005). Who is earning, who is entitled to claim and receive means-tested payments, and how household income is accessed and distributed in different partnership and household configurations therefore comes sharply into focus. The focus is particularly keen for cohabiting couples because, unlike spouses, cohabitees are under no legal obligation to financially support one another. Furthermore, unlike child maintenance which requires financial contributions to be evidenced, there is no legal obligation on the main claimant to transfer any part of the payment to his or her partner. Lone parents who fail to disclose a relationship that could 
be deemed to be marriage-like expose themselves to further risk since such a 'determination,' as it is called, may constitute benefit fraud.

This 'Hobson's choice' between dependency on a partner or dependency on the state is often the context in which women reliant on state financial support are obliged to conduct their intimate relationships. Long criticised by feminists for the violation of women's citizenship and equality rights (Lister, 2001), and the reinforcement of women's economic dependency (Bennett, 2012), it has been speculated that enforced dependency on a partner and restricted access to an independent income could undermine relationship stability in couples and potentially deter some lone mothers from repartnering (Lister and Bennett, 2010; Bennett and Annesley, 2011). However, to date, these potential effects have not been investigated empirically. The distinctiveness of this research was in conjecturing that family structure, household composition and living arrangements in low-income families may as much be a product of the influence of structural constraints, arising from these regulatory and administrative aspects of the welfare system, as they are a result of women's 'lifestyle choice' in response to cultural influences or financial incentives. Using interviews with mothers to highlight the subtle and unseen ways in which means-tested welfare can affect family functioning at a household level, its original contribution was to offer new empirically informed insights into the ways in which the welfare system can affect gender relations, relationship stability and living arrangements.

\section{Ethical considerations}

By 'generating nuanced accounts that subvert established knowledge' (Lewis, 2008: 562), personal testimonies have the capacity to challenge hegemonic and stigmatised discourses (Lister, 2002). However, with interviews here exploring mothers' intimate relationships and welfare histories and potentially touching upon sensitive, even incriminating issues, ensuring confidentiality, anonymity and informed consent was of paramount importance. The ethical approach was strongly informed by the legal position in respect of any potentially incriminating disclosures made. Researchers have the same legal obligations as any other private citizen regarding any requirement to disclose information in connection with illegal or criminal activity which emerges during research (Corti et al., 2000). Unless they actually witness an offence being committed, such information is likely to be deemed as hearsay (Israel, 2004). The approach adopted was therefore to use any disclosures of fraud or criminality in a beneficial way which would broaden understanding of the reasons and circumstances under which such unlawful activity may have been carried out, thus contributing to better informed social policy.

Family support workers were used to help recruit participants; their knowledge and the trusted relationships they had with local mothers proved 
invaluable. Care was taken to exclude vulnerable individuals for whom participation might cause them undue distress or threaten their or their children's well-being, and mothers were only recruited who fully understood the purpose of the study including how interview transcripts would be used and where findings might be published. Participants were reassured that they could decline to answer any questions and were at liberty to withdraw from the research at any time. To protect their anonymity, aliases were used throughout and no address or surname was taken. Small personal details were also altered during the writing up of findings and the attribution of quotes.

Informed thus by the ethical guidelines of the Social Research Association (Social Research Association, 2003) and the Statement of Ethical Practice of the British Sociological Association (British Sociological Association, 2002), ethical approval for the study was secured from the University of Bath Research Ethics Committee.

\section{Sampling and analysis}

Understanding the 'how' and 'why' of partnership trajectories required a sample capable of capturing a spectrum of relationship types and partnership transitions, not simply those which correspond to static categories of marital or partnership status (Osborne and McLanahan, 2007). A heterogeneous sample of 51 mothers was therefore recruited which included never-married, separated and divorced lone mothers as well as those who had since repartnered or remarried. 26 ( 52 per cent) had become lone parents through separation or divorce from a spouse or partner; 23 ( 45 per cent) had not been in a co-residential relationship with a partner at the time of a child's birth; and 2 had been widowed. At the time of being interviewed, 27 had no partner, 13 had a partner living elsewhere, 6 were cohabiting and 5 were living with a husband. A sample thus structured was not intended to be representative but rather to reflect the different routes of entry into and exit out of lone motherhood. Participants were also recruited from a variety of social backgrounds and with varying levels of education and employment experience. Restricting the sample to only young, poor, unemployed or disadvantaged lone mothers could have risked generating self-fulfilling findings which feed into stigmatised discourses.

Transcribed data were coded and analysed using MAXQDA 10, a Computer Assisted Qualitative Data Analysis (CAQDAS) software package that lends itself well to iterative and interpretive forms of qualitative analysis (Kuş Saillard, 2011). Key themes and issues were analysed inductively, as issues emerged from interview transcripts, using concepts and theories about welfare and family relationships drawn from economic and sociological disciplines. This exploratory approach reflected the fact that, to date, no single theory has been able to account for the multiple pathways of partnership formation and dissolution, and no simple 
analytical model or framework has been developed with which to examine the different dimensions of family change (Rowlingson and McKay, 2005).

Though a relatively diverse sample was achieved, as is the case for most research using purposive methods, 'the canons of testability ... and sampling ... do not apply' (Eisner, 1981: 7). Findings are therefore not generalisable beyond the specific geographic context and group of mothers interviewed.

\section{Deterrents to living with a child's father}

Among mothers who were currently living apart, or had previously lived apart, from a child's father, the research found that means-tested welfare rules entailing the loss or reduction in entitlement to benefits or tax credits, together with male partners' low-paid or insecure work, formed a key part of the context in which the decision had been made. Miriam was fairly typical. Her partner's low wage was a key reason for the couple's decision to live apart: 'I work part time and ... get Working Tax Credits ... Housing Benefit and help towards childcare costs. ... That gets me by ... I'd lose all that if I moved in with him ... We'd have to live on his wage if we were living together ... we'd have hardly anything to live on... We struggle as it is ... so we just can't do it at the moment (Miriam, 23, one child aged 18 months). The couple tolerated the arrangement because it was seen as temporary, until Miriam secured better-paid work: 'We chose to live separately ... until I finish my nurse training ... so it means I'm going to have a better-paid job in three years and be able to move in together.'

Maggie, too, was reluctant to relinquish the financial autonomy she had secured after separating from her spendthrift partner. Maggie had previously claimed benefits jointly with her child's father but, after their relationship broke down, she came to relish her new-found financial independence as a lone parent, taking solace in the network of support provided by her family. 'I was financially stable, I was independent with my money... if I needed anything ... my mum and dad were always there to help ... it was a really strong family network ... so I felt quite secure' (Maggie, 23, one child aged 4). Two years after they separated, this couple repartnered, but Maggie was in no hurry for them to move back in together. Becoming financially dependent on her partner again did not sit well with her and was premature. 'If he moved in now, it would be me basically living off him, which I'm not comfortable with, I don't want it!' Living together would have to wait, she said, until her child started school and both she and her partner were earning and no longer reliant on benefits.

Knowing her partner's history of insecure employment and indebtedness, Cheryl wanted to 'test the waters' before formally committing herself to living together: 'One minute he'd be in a job, the next minute he wouldn't be working ... With having [children], I couldn't be like that, I had to make sure the bills were paid ... I said ... 'I'm not going to move you in and like declare it straight away if ... 
you're not going to step up to the mark' (Cheryl, 27, three children aged 10, 6 and 4). When her partner did fail to 'step up,' the relationship ended, vindicating, she believed, her decision not to cohabit. Staying for most of the week at a different address, hanging out with friends and 'bobbing in and out' as the fancy took him, Cheryl conjectured that the independent lifestyle this living arrangement allowed her partner, and his ability to 'up and go when the going got tough,' were important contributory factors in the relationship's demise.

Though sympathetic to couples' difficult financial circumstances and non-judgemental, support workers, too, believed that maintaining separate households could potentially undermine relationship commitment and responsible co-parenting. 'If you've got a bolthole to go to, well you can drop a bomb and go can't you? You don't have to stay for the fall out' (Family support worker). Occupying two properties instead of one was also seen to be wasteful: 'It's such a waste of resource ... where the amount of Housing Benefit is going on empty properties, that's the thing ... when housing is in need' (Family support worker).

Somewhat ironically, it was a shortage of social housing that had obliged Amy and her partner to live separately. With no means of acquiring the estimated $\mathfrak{E} 1,000$ the couple needed to start renting privately, Amy's only option after having her baby was to relocate from a homeless young person's hostel into lone mothers' supported housing. Though grateful for the accommodation, Amy struggled with living apart from her partner at what should have been a private and intimate time: 'You're not allowed to have your boyfriend stay ... you can't be together ... it's a mum and baby unit, you're not really meant to have dads here ... just to visit ... He comes here after work to see the baby and see me ... and we sit together for a little bit' (Amy, 22, one child). As her support worker explained: 'Here it would be fraudulent if couples cohabited because [the mother] is the one who gets the housing [benefit]'.

It was not only young unmarried mothers or those in unstable partnerships whose relationships and living arrangements could be impacted by welfare rules. When Madeleine's husband has his Jobseekers Allowance (JSA) claim stopped after an administrative mix up, the family's ensuing rent arrears and debt culminated in serious rows and, for the sake of the children, the couple separated. She claimed Income Support as a lone parent and her estranged husband moved out, claiming JSA as a single man. Tentatively rebuilding their relationship while living apart, before ending her lone-parent claim and reuniting the family in a shared household, this mother needed the reassurance that her husband was securely employed: 'I want to see that he's been working for a while and to show me... the wage slips ... to prove that he is getting paid ... Ineed to know that we're going to be secure ... that I can pay my bills ... that's the most important thing ... so he'd have to be working for a bit before I came off the benefits and I think we'd have to sort of transition' (Madeleine, 35, three children aged 12, 8, 4). By claiming benefits as individuals, the family had regained a degree of financial stability 
that had been disrupted by the father's unemployment and the consequences of claiming benefits as a couple. Paradoxically, and contrary to welfare discourses denouncing family breakdown and couples who 'pretend to live apart', by living in separate households, this family was just about managing to stay together.

\section{Deterrents to living with a new partner}

For mothers in the tentative stages of progressing to a more committed phase of a new relationship, family-based means testing and the LTAMC rule raised uncomfortable dilemmas, affecting early partnership dynamics and decisions about whether and when to cohabit. With no official acknowledgement of the different stages or types of couple relationships, Nina challenged the indiscriminate way in which the LTAMC rule forces lone parents into financial dependency on a new partner the minute he moves in. Nina was a graduate with three children who worked part-time in a low-paid job topped up by Working Tax Credit (WTC). After seven years as a lone parent, she began dating a new, working partner. When he later rented out his house and moved in, Nina delayed informing HMRC. 'At the time I first got together with my new partner ... I didn't advise ... the benefits agencies ... I didn't feel I was defrauding anybody, although technically I realise I was. I felt that I was right because [new partner] hadn't played a part in the children's lives up to that time ... So I thought it was unfair that we would be considered to be cohabiting in a way that meant he was responsible for providing for me and the children (Nina).

The assumption that household income and resources should be pooled by couples was an aspect of means-tested welfare that Nina, along with several other mothers, strongly took issue with. Though accepting that jointly incurred household expenses should be a shared responsibility, she questioned welfare rules that oblige a new partner to assume financial responsibility for a mother and her children, something she vehemently defended as belonging to herself and the children's father. In common with others, Nina drew a clear distinction between parenting and partnering. 'There's a huge difference between being a partner and a parent ... I will always value ... the stability that [new partner] brought to our lives but he wasn't our provider ... I don't consider him their father and nor does he. So why should he be responsible for them financially?' That couples who live together should automatically lose their right to claim as individuals was similarly contested. 'What I don't agree with ... is that if you live together you suddenly become totally intertwined with your finances ... It should be irrelevant if you're living as a couple or ... as two housemates ... Yet the benefits system doesn't see things that way. If you're a couple, one is dependent on the other... that doesn't make sense' (Nina). In continuing to claim tax credits, she justified her actions in terms of the newness of the relationship and the temporary nature of the deception; after a year cohabiting, she withdrew her claim. 'I did it because I 
didn't think that [new partner] should have to support me and my children. So ... although I was financially better off in that situation, that wasn't why I did it'. Had continuing her claim not been possible, she was adamant that the trajectory of her new relationship would have followed an entirely different path: 'If his wages had to pay for all of us ... if I would have had to have been completely financially dependent on him .... I wouldn't have done it' (Nina).

This conflation of cohabitation and co-residency in social security rules (Kelly, 2008) was similarly challenged by Lorena, a graduate teaching assistant who had been separated from her husband for six years. When she began dating a new, high-earning partner, she found herself on the horns of a dilemma; whether to continue claiming as a lone parent and risk being prosecuted for benefit fraud, or to end her claim and ask her new partner to financially support her: 'I felt that they're putting me in position now where I have to be dependent on someone who really was not supporting me financially ... He was just a person who dated me ... We're not married, he was not responsible for me or [my child] financially' (Lorena, 38, one child aged 9). Requiring new couples to become financially dependent on each other could adversely affect relationship dynamics and inhibit commitment, she believed: 'How badly as a woman you would feel ... It's a little bit like prostitution isn't it because you are there in a relationship that is just starting out and then someone is financially responsible for you ... How can I just say, 'actually ... can you give me money?'... It would destroy, not build a relationship' (Lorena). Faced with an uncomfortable choice between two equally unpalatable alternatives, Lorena arrived at a compromise. Even though her partner had his own house and was not financially supporting her, fearful that someone might report her for cohabiting, she withdrew her claim for Housing Benefit. However, unwilling to ask her partner for money so early in their relationship but with a high rent to pay, she continued to claim WTC for a year as a lone parent.

Untypical of the sample as a whole, these middle-class, well-educated mothers had re-partnered with high-earning partners financially capable of supporting them and their children, yet still they resisted financial dependency, not covetously for monetary gain but because this enabled them to retain their financial independence at the beginning of a new relationship when its course was uncharted and the outcome uncertain.

\section{Remaining unpartnered}

Anxious to avoid the potentially damaging effects on a child's emotional wellbeing of a relationship that did not endure, young single mothers often ruled out any form of partnership in the short term. Of central concern was the loss of income and financial independence that living with a partner was seen to entail. 'I've always been quite independent ... If I did ... get in a relationship ... and we wanted to live together, they'd expect a man to keep me and my child that 
wasn't his. So they'd pretty much stop ... all my money' (Tricia, 31, one child aged 4). Not only was enforced financial dependency felt to be unacceptable in the context of a modern-day relationship but, as several mothers pointed out, when a woman's partner is not the biological father of her child or children, the stakes are considerably higher. 'The umbrella of money is for all of you, it's not just for you ... it's for the couple. They don't take into account that he's not that person's child, they just take into account how much is coming into the household... I certainly would never expect a man to keep me, even if he was the father. I've always been very independent with money... so that ... would have stopped anything from going any further' (Tricia).

Requiring one partner to be financially dependent on the other was believed to alter power relations in couples. 'If it wasn't my money, it wouldn't be my place to say anything ... it would make me worry ... You'd be thinking ... if I say something he doesn't like, are we going to be out on our ear? And I think that would stop me a little bit from committing to that relationship... With a child, they need ... a roof over their head, stability, so that would stop me' (Tricia). The very imposition of such a financial obligation might itself inhibit relationships from blossoming: 'People talk about kids being baggage ... but in this situation it's right isn't it? I think it would certainly put a strain on the relationship'. Being subject to a partner's compliance and satisfactory fulfilment of conditionality requirements was an added factor of concern: 'When you're in a couple and you have a child ... the tax credits and everything go in his bank account and if [he] doesn't sign on, we don't get paid ... I don't think I'd want to trust someone with whether I'm getting paid for my son' (Fria, 21, one child aged 2).

Such anxieties about the financial implications of relinquishing lone-parent status and the greater insecurity of cohabiting relationships strongly resonated with the views of support workers. Some routinely advised lone mothers to retain their financial independence, if necessary, by living separately from their partners. 'Who gets the benefits is a huge issue and I've traditionally always advised the mum that she needs to get the benefit, she's the mum, she's getting child benefit, child tax credits ... Mums by and large are far more reliable in terms of actually what they spend the money on. It's all about priorities, rent, food, bills... And mum's going to be worried, I don't blame her, all that ... transience and unreliability' (Welfare rights worker).

\section{Discussion}

Through highlighting the subtle but significant ways in which enforced obligations of financial dependency and support can deter cohabitation and discourage repartnering among mothers eligible for means-tested benefits and tax credits, this empirical study contributes to understanding about the nature of the relationship between welfare receipt, gender and family structure. In recent 
policy discourse, this association is seen to arise largely in response to the influence of financial differentials in entitlement said to incentivise lone parenthood while 'penalising' two-parent families (Duncan Smith, 2011). Individualisation theory, on the other hand, interprets lone motherhood and 'living apart together' (LAT) as alternative family forms which some women choose in preference to living with a partner because they value their autonomy and independence (Levin, 2004). In this research, neither the 'couple penalty' nor the individualisation hypothesis adequately captured the complexity, range or diversity of circumstances in which a mother's decision to live apart from a partner or child's father had been made; neither the simple desire for more money, nor the wish to 'go it alone,' were accurate or sufficiently nuanced explanations. Rather, by removing a mother's entitlement to claim in her own right and obliging her to be financially dependent on her partner, it was the loss of income and financial autonomy resulting from family means testing and the LTAMC rule that had been most influential in decisions about whether and when to cohabit or disclose a cohabiting partnership. In these instances, a key driver of partnering behaviour was not what these women stood to gain financially by becoming or presenting themselves as a lone parent, but rather what they lost or stood to lose by being or becoming part of a couple. Although financial issues often dominated mothers' thinking, their accounts therefore give lie to the simplistic notion that some women 'choose' to become lone mothers or 'pretend' to separate in order to become eligible for higher levels of financial support.

Referencing Duncan and Edward's theory of 'gendered moral rationalities' and Millar and Ridge's research exploring lone mothers' labour market supply (Millar and Ridge, 2001; Duncan and Edwards, 2003), findings highlight the significance of women's role and agency as mothers as providing the context within which demographic decision-making is often framed. Reflecting US studies, indicating women's role as mothers to be pre-eminent in shaping family formation behaviour, prioritising the well-being of their children above that of any partner strongly underpinned these mothers' decisions about whether and when to embark upon a co-residential partnership (Edin and Kefalas, 2006; Nelson, 2006). The state of being together as a couple and family, but not living together in the same household, also resonates with US research which shows how complex household configurations and living arrangements can enable poor couples to establish a basis for continued interaction as parents and intimates (Cross-Barnet et al., 2011). In a similar way, by decoupling parenting from partnering, in this study, 'living apart together' arrangements often functioned as a mechanism to allow these couples a legitimate means, as they saw it, of conducting intimate or parenting relationships without fear of criminal prosecution.

That deterrent effects to being or becoming a two-parent family were experienced regardless of a mother's social, employment or marital status also 
provides reinforcing evidence that structural factors associated with the design of means-tested welfare were important drivers of partnering behaviour and living arrangements. In revealing that married, middle-class and well-educated mothers behaved in similar ways to unpartnered, never-married mothers, the findings thus contribute to research challenging underclass discourses which stigmatise poor single mothers as welfare dependents with inadequate parenting skills and deviant set of family values (Dermott and Pomati, 2016).

More broadly, the findings suggest that, for low-income women reliant on means-tested state financial help, in contrast to the protection family formation is generally assumed to provide, living as a two-parent family can be an inherently risky business. Whereas, historically, male breadwinners offered women with little or no independent income a measure of economic protection, in the context of a precarious labour market for low-skilled men and an increasingly stringent welfare system for claimants and their partners, far from being protective, living together as a couple has come to represent an arena of increasing uncertainty, insecurity and risk. In this study, rather than an expression of individualism or a pecuniary response to differential levels of welfare entitlement between lone and couple parents, maintaining a measure of financial independence through becoming or remaining a lone mother, was largely a matter of economic necessity. Although lone motherhood was not without its own challenges and risks, the financial safety net provided by the welfare state was perceived by these mothers to offer a better chance of security and family stability than becoming dependent on an unreliable 'breadwinner' or on a new, unproven partner. That the balance of decision making fell more heavily on the side of getting by as a lone parent was all the more compelling if a mother's partner was not the child's father.

In this context, resisting economic dependency by retaining lone-parent status, by living apart from a partner or child's father, or by remaining unpartnered, can be seen as a means of managing and mitigating risk under conditions of economic and relationship uncertainty. Out of step with contemporary relationship norms and liable to reinforce gender inequality inside the household, by obliging the members of a couple to be financially dependent on each other, joint means testing and the LTAMC rule acted as a significant deterrent to family formation and repartnering. Paradoxically, these unintended outcomes - couples living apart, increased risk of relationship instability, a father's absence from the family home, together with possible detrimental effects on children are precisely the adversities family and welfare policies are put in place to counter.

\section{Implications for policy}

Such unintended effects have important implications for policy. Universal Credit (UC), which merges six means-tested benefits into a single payment, is currently being rolled out nationally in phases (Department for Work and Pensions, 2010b). 
Couples living together in the same household are jointly assessed for Universal Credit and treated as a single 'benefit unit,' as they always have been. However, in a significant departure from legacy benefits, the aggregated amount of UC is paid in the form of a single, monthly payment per household, transferred into a single bank or building society account (Department for Work and Pensions, 2011). Couples are free to choose into which account the money is paid but, other than in exceptional circumstances, ${ }^{3}$ they will not be able to choose to have the payment split between the partners, effectively reversing the previous policy which allowed WTC and Child Tax Credit (CTC) to be paid to the nominated 'main carer'. Given that, in 85 per cent of couple households, CTC is currently paid to a female carer, this reform is likely to disproportionately affect women, something which the government's equality impact assessment of UC singularly failed to acknowledge (Department for Work and Pensions, 2010a).

UC rules governing work conditionality for couples are also 'substantially more demanding' (Bell and Brewer, 2012). Although couples with dependent children are able to nominate a lead carer, both partners are required to look for work and sign a 'claimant commitment' obliging them to increase hours of employment until a combined earnings threshold is reached ${ }^{4}$. This extends conditionality to an entirely new group - working families with children, including the partners of low-earning adults, a majority of whom are women. Even though they may not have access to or benefit from the payment, women claiming UC jointly will also be subject to any sanctions or fines imposed on their partners as well as legally liable to repay any overpayments due to fraud or error.

Academics and campaign organisations have sought to raise awareness of the implications that UC's unitary household model and 'purse to wallet' income transfers could have on women's economic independence, couples' management of their household finances and child poverty (Women's Budget Group, 2011a; Bennett and Sung, 2013). Resonating strongly with these concerns, by eroding women's financial independence more than under the legacy system, the evidence from this research suggests that, for couples who live together, paying UC in the form of a monthly, undifferentiated award into a single bank account, together with the extension of work conditionality to claimant's partners, could create an added burden of risk in terms of relationship stability, especially for those in inegalitarian, controlling or abusive relationships. For lone mothers contemplating moving in with a new partner, 'a significant leap of faith' would indeed seem to be required (Women's Budget Group, 2011b).

\section{Options for reform}

Since encouraging behaviours conducive to family stability is an explicit goal of social policy across the political spectrum, findings reinvigorate arguments in 
favour of reforming the social security system in ways which increase the financial independence of claimants who live together, or would like to. But what are the options and how can reform be argued in the current fiscally constrained policy environment? Disaggregation - operating the welfare system according to the same principles of individual and separate treatment as applies to the income tax system - would cancel out many of the disincentive effects to co-residential partnering highlighted in this research; being individualised, ${ }^{5}$ the current tax system generates negligible incentives either for or against cohabitation, marriage, family formation or dissolution (Anderberg, 2008). However, each time such a proposal has been advocated, it has been unequivocally rejected due to the prohibitive cost and the 'unwarranted inequities of paying benefits to partners of prosperous husbands and wives' (Department of Health and Social Security, 1978). A more modest reform would be to allow newly cohabiting couples a period of grace of living together of perhaps 6 or 12 months before joint assessment was imposed. However, a key drawback here is that the underlying assumption of economic dependency in couples (and so the potential deterrent effects on cohabitation and family formation) is only temporarily deferred, not overturned. Relaxing the LTAMC rule has also always officially been resisted on a matter of principle that it would be unfair to treat cohabitants more favourably than married couples (Department of Health and Social Security, 1978).

Removing or reducing the financial differential between lone parents and couples could help to address the perceived unfairness of paying couples less than double the amount awarded to lone parents, as well as the inconsistent treatment of couples compared with the adult members of a shared household who remain entitled to claim as individuals ${ }^{6}$. However, the largest element of the 'couple penalty' arises due to joint means testing in which couples' needs and income are aggregated. Reducing the differential in entitlement between lone and couple parents would therefore only have limited impact on the financial disincentive faced when a lone parent starts to cohabit (Lister and Bennett, 2010). Furthermore, simply increasing the amount of benefit couples are entitled to is no guarantee that the additional money awarded would be equally distributed or accessible to both partners in a couple.

Interest in the idea of a Basic Income - a universal, unconditional payment made to all citizens - has recently been gaining momentum (Torry, 2013). Its advantage over simply individualising assessment and entitlement is the wholesale elimination of means testing and conditionality, thereby removing all incentive and disincentive effects to partnership formation and dissolution, as well as to paid work by either partner in a couple. However, the radical nature of the policy and potentially high cost to the public purse means that the proposal seems unlikely to be adopted by any mainstream UK political party in the foreseeable future. Increasing the earnings disregard available to couples by introducing an additional work allowance for second earners would help to 
counterbalance women's potential loss of access to the single UC payment and is less controversial, but this too has public expenditure implications. A fiscally neutral and less politically contentious adjustment to UC's payment regime would be to equally divide, or allow jointly claiming couples to split, the single monthly payment - flexibilities currently being considered by the devolved UK governments in Scotland and Northern Ireland. If implemented, the comparative effects on couples of different UC payment regimes in the devolved nations will be important to monitor.

None of this is to suggest that two-parent families should be upheld as the ideal family form but simply that, based on the evidence in this study, enabling women (and men) to retain access to an independent income when living together as a couple is likely to provide a sounder basis for relationship commitment and family stability. Without some policy adjustment to welfare rules, which currently remove a woman's entitlement to claim means-tested benefits in her own right if she lives with a partner, the government's claim that 'the formation of couple relationships is a private matter for individuals' (Department for Work and Pensions, 2014) has something of a hollow ring.

\section{Acknowledgements}

This $\mathrm{PhD}$ research received a University Research Scholarship excellence award, and the support of the University of Bath in granting this funding is gratefully acknowledged. The author would also like to sincerely thank all the research participants who volunteered to take part in this study. The constructive comments received from three anonymous reviewers on an earlier draft were also invaluable.

An earlier version of this paper was awarded the Social Policy Association's (SPA) Best Postgraduate Paper at the SPA Annual Conference in Belfast, 2015.

\section{Notes}

1 Saving eligible couples a maximum of $\mathfrak{E} 212$ a year, its reintroduction is largely symbolic.

2 Also known as the 'cohabitation rule'.

3 Exceptional circumstances include where there is proven abuse of the money, where the claimant is being sanctioned, where there is fraud and, for those with children, where there is serious risk of losing their homes.

4 The rules governing work conditionality in couples are complex and vary depending on the age of the youngest child and joint household earnings. For couple families where the youngest child is aged 12 or over, the combined earnings threshold is equivalent to the two adults working full time at the national minimum/living wage.

5 With the exception of the reintroduced married couples tax allowance.

6 This includes lone parents who live with other family members.

\section{References}

Anderberg, D. (2008), 'Tax credits, income support, and partnership decisions', International Tax and Public Finance, 15 (4), 499-526. 
Barlow, A., Duncan, S. and James, G. (2002), 'New Labour, the rationality mistake and family policy in Britain', in A.H. Carling, S. Duncan and R. Edwards (eds), Analysing families: morality and rationality in policy and practice, 110-128, London: Routledge.

Bell, K. and Brewer, M. (2012), 'Changes to the Working Tax Credit may not always make work pay and raise serious questions about fairness', [online] available from: http://blogs.lse.ac.uk/politicsandpolicy/2012/03/20/house-rules-and-tax-credits (accessed $07 / 04 / 13)$.

Bennett, F. (2005), Gender and Benefits. Working paper Series No. 30, Manchester: Equal Opportunities Commission.

Bennett, F. (2012), 'Universal Credit: an overview and gender implications,' presentation based on work for Women's Budget Group and on research conducted with Dr Sirin Sung, Queens University Belfast, University of Oxford, Department of Social Policy and Intervention, [online], available from: http://ppu.politics.ox.ac.uk/ past_materials/bennett_may2012.pdf (accessed 10/04/13).

Bennett, F. and Annesley, C. (2011), 'Universal Credit may reinforce the traditional male breadwinner model and affect many women's access to an income', [online] available from: http://blogs.lse.ac.uk/politicsandpolicy/universal-credit-inequality/ (accessed 20/05/13)

Bennett, F. and Sung, S. (2013), 'Gender implications of UK welfare reform and government equality duties: evidence from qualitative studies', Oñati Socio-Legal Series, 3:7, 1202-1221.

Blau, D. M. and Van Der Klaauw, W. (2013), 'What determines family structure?' Economic Inquiry, 51 (1) 579-604.

Bradshaw, J. (2011), The well-being of children in the UK, University of Bristol: Policy Press.

Brewer, M., Ratcliffe, A. and Smith, S. (2012), 'Does welfare reform affect fertility? Evidence from the UK', Journal of Population Economics, Volume 25, Issue 1, 245-266.

British Sociological Association (2002), 'Statement of ethical practice for the British Sociological Association', British Sociological Association, [online] available from: https://www.britsoc.co.uk/equality-diversity/statement-of-ethical-practice/ (accessed 22/06/13).

Chapman, J. (2011), 'Couples turn to benefit fraud because we don't support marriage says Iain Duncan Smith as he attacks Britain's 'crazy' welfare system', [online], available from: http://www.dailymail.co.uk/news/article-1354699/Iain-Duncan-Smith-Couples-turnbenefit-fraud-welfare-doesnt-support-marriage.html (accessed o7/01/13).

Corti, L., Day, A. and Backhouse, G. (2000), 'Confidentiality and informed consent: Issues for consideration in the preservation of and provision of access to qualitative data archives', Forum Qualitative Sozialforschung: Qualitative Social Research, 1 (3).

Crawford, C., Goodman, A., Greaves, E. and Joyce, R. (2012), 'Cohabitation, Marriage and Child Outcomes: An Empirical Analysis of the Relationship between Marital Status and Child Outcomes in the UK Using the Millennium Cohort Study', Child and Family Law Quarterly, 4 (2), 176-198.

Cross-Barnet, C., Cherlin, A. and Burton, L. (2011), 'Bound by Children: Intermittent Cohabitation and Living Together Apart,' Family Relations, 60 (5), 633647 .

Department for Work and Pensions. (2010a), Equality Impact Assessment, Universal Credit: welfare that works. London: DWP.

Department for Work and Pensions (2010b), White Paper on Universal Credit. London: DWP.

Department for Work and Pensions (2011), Universal Credit Briefing Note 2: The payment proposal. London: DWP.

Department for Work and Pensions (2014), The Family Test: Guidance for government departments. London: DWP.

Department of Health and Social Security (1978), Social Assistance: A reveiw of the Supplementary Benefit scheme in Great Britain London: DHSS.

Dermott, E. and Pomati, M. (2016), 'The parenting and economising practices of lone parents: Policy and evidence', Critical Social Policy, 36 (1), 62-81. 
Duncan, S. and Edwards, R. (2003), 'State welfare regimes, mothers' agencies and gendered moral rationalities', in Kollind, K. and Peterson, A. (eds), Thoughts on family, gender, generation and class. Sociologiska Institutionen, Göteborgs Universitet, 2-23.

Duncan Smith, I. (2011), Iain Duncan Smith, Speech to Conservative Party conference, 3rd October 2011, [online] available from: http://www.politics.co.uk/comment -analysis/2011/10/o3/iain-duncan-smith-speech-in-full (accessed 12/12/13).

Edin, K. and Kefalas, M. (2006), Promises I can keep: Why poor women put motherhood before marriage, Berkeley: University of California Press.

Eisner, E. W. (1981), 'On the differences between scientific and artistic approaches to qualitative research', Educational Researcher, Volume 10 (4), 5-9.

Israel, M. (2004), 'Strictly confidential? Integrity and the disclosure of criminological and socio-legal research,' British Journal of Criminology, 44 (5), 715-740.

Kellner, P. (2012), 'Charity ends at home,' [online] available from: http://www. huffingtonpost.co.uk/peter-kellner/charity-ends-at-home_b_1303384.html (accessed $17 / 08 / 13)$.

Kelly, S. (2008), 'The Truth about Cohabitation', School of Social and Policy Science: University of Edinburgh.

Kiernan, K. (2006), 'Non-residential fatherhood and child involvement: Evidence from the Millennium Cohort Study', Journal of Social Policy, 35, 651-669.

Klett-Davies, M. M. (2012), Going it alone? Lone motherhood in late modernity, London: Ashgate Publishing Ltd.

Kuş Saillard, E. (2011), 'Systematic versus interpretive analysis with two CAQDAS packages: NVivo and MAXQDA', Forum:Qualitiative Social Research, 12 (1).

Levin, I. (2004), 'Living apart together: A new family form', Current Sociology, 52 (2), 223-240.

Lewis, D. (2008), 'Using life histories in social policy research: the case of third sector/public sector boundary crossing', Journal of Social Policy, 37 (4) 559-578.

Lister, R. (2001), 'Towards a citizens' welfare state - The $3+2$ 'R's of welfare reform', Theory, Culture and Society, 18 (2-3), 91-111.

Lister, R. (2002), 'A politics of recognition and respect: involving people with experience of poverty in decision making that affects their lives', Social Policy and Society, 1 (1), 37-46.

Lister, R (ed) (1996), Charles Murray and the underclass: The developing debate. London: Institute for Economic Affairs (IEA) Health and Welfare Unit.

Lister, R. and Bennett, F. (2010), 'The new 'champion of progressive ideals. Cameron's Conservative Party: poverty, family policy and welfare reform', Renewal, 18 (1/2), 84-109.

Macdonald, R., Shildrick, T. and Furlong, A. (2014), 'In search of 'intergenerational cultures of worklessness': Hunting the Yeti and shooting zombies', Critical Social Policy, 34 (2), 199-220.

Macnicol, J. (1994), 'Is there an Underclass? The Lessons from America', in M. White (ed.) Unemployment, Public Policy and the Changing Labour Market, 29-39, London: Policy Studies Institute.

Mann, K. and Roseneil, S. (1994), 'Some Mothers Do 'Ave 'Em': Backlash and the gender politics of the underclass debate', Journal of Gender Studies, 3 (3), 317-331.

McLanahan, S. (2009), 'Fragile Families and the Reproduction of Poverty', Annals of the American Academy of Political and Social Science, 621, 111-131.

Middleton, S. (2011), 'I Wouldn't Change Having the Children-Not at All.' Young Women's Narratives of Maternal Timing: What the UK's Teenage Pregnancy Strategy Hasn't Heard', Sexuality Research and Social Policy, 8 (3), 227-238.

Millar, J. and Ridge, T. (2001), Families, Poverty, Work and Care: A review of the literature on lone parents and low-income couple families with children, DWP Research Report No. 153, London: DWP.

Morgan, D. H. (2011), Rethinking family practices, London: Palgrave Macmillan.

Morgan, P. (2008), 'The impact of tax and benefits on family structure', Occasional Paper 38. Berlin: Liberales Institut.

Murray, C. (1989), 'Underclass', Sunday Times Magazine, 26th November 1989. 
Nelson, M. K. (2006), 'Single mothers “do" family', Journal of Marriage and Family, 68 (4), $781-795$.

ONS (2015), Families and households: 2015, London: Office for National Statistics.

Osborne, C. and McLanahan, S. (2007), 'Partnership instability and child well-being', Journal of Marriage and Family, 69 (4), 1065-1083.

Prideaux, S. J. (2010), 'The welfare politics of Charles Murray are alive and well in the UK', International Journal of Social Welfare, 19 (3) 293-302.

Robinson, F. and Gregson, N. (1992), 'The 'underclass': a class apart?', Critical Social Policy, 12 (34), 38-51.

Roseneil, S. (2006), 'On not living with a partner: Unpicking coupledom and cohabitation', Sociological Research Online, 11 (3).

Rowlingson, K. and McKay, S. (2005), 'Lone motherhood and socio-economic disadvantage: insights from quantitative and qualitative evidence', Sociological Review, 53 (1), 30-49.

Shildrick, T., MacDonald, R., Furlong, A., Roden, J. and Crow, R. (2012), Are 'cultures of worklessness' passed down the generations?, York: Joseph Rowntree Foundation.

SJPG (2006), The State of the Nation Report: Fractured families, London: Social Justice Policy Group.

Social Research Association (2003), Ethical guidelines [online] available from: http://www.thesra.org.uk/documents/pdfs/ethicso3.pdf. (accessed 27/01/12)

Taylor-Gooby, P. and Martin, R. (2008), 'Trends in sympathy for the poor', in Alison Park, John Curtice, Katarina Thomson, Miranda Phillips, Mark Johnson and Elizabeth Clery (eds), British Social Attitudes: The 24th Report, 229-237.

The Centre for Social Justice (2010), Green Paper on the Family, London: The Centre for Social Justice.

Torry, M. (2013), Money for everyone, University of Bristol: Policy Press.

Upton-Davis, K. (2012), 'Living Apart Together Relationships (LAT): Severing Intimacy from Obligation', Gender Issues, 29 (1-4) 25-38.

Walker, I. and Zhu, Y. (2006), Child Support and Partnership Dissolution. The Economic Journal, 116 (510), 93-109.

Webster, D. (1999), 'Lone parenthood: Two views and their consequences', in Anderson, 1. and Simm, D. (eds) Social Exclusion and Housing: Context and Challenges. Coventry: Chartered Institute of Housing and Housing Studies Association.

Women's Budget Group (2011a), 'Universal Credit: payment to joint claimants', Committee stage of Welfare reform Bill 2011, London: House of Lords, Oct 2011 (Clause 97).

Women's Budget Group (2011b), Welfare Reform Bill 2011, 'Universal Credit payment issues: Briefing from Women's Budget Group', London. 